\title{
Homogeneity Analysis of MDF in Parallel and Perpendicular Directions Related to Panel Production
}

\author{
Marília da Silva Bertolini ${ }^{1}$, Fabiane Salles Ferro ${ }^{1}$, Márcio Rogério da Silva ${ }^{2}$, Carlito Calil Neto ${ }^{3}$, \\ André Luis Christoforo ${ }^{4, *}$, Francisco Antonio Rocco Lahr ${ }^{3}$ \\ ${ }^{1}$ Department of Science and Material Engineering, Engineering School of São Carlos (EESC/USP), São Carlos, 13566-590, Brazil \\ ${ }^{2}$ Department of Biosystems Engineering, São Paulo State University (FZEA/USP), Pirassununga, 13635-900, Brazil \\ ${ }^{3}$ Department of Structural Engineering, Engineering School of São Carlos (EESC/USP), São Carlos, 13566-590, Brazil \\ ${ }^{4}$ Department of Civil Engineering, Federal University of São Carlos, São Carlos, 13565-905, Brazil
}

\begin{abstract}
MDF in Brazil is an almost recent product, available in the market from the late ' 80 s. The resin content appears as one of the factors that most influence the final properties of MDF panels. Identification of how these factors interact is very useful for improving performance and energy inputs, determining ideal resin content based on the desirable properties. This paper analyzes the most important properties of a MDF panel in the industry, in directions: perpendicular and parallel to the direction of production, thus verifying the homogeneity throughout the panel, according to EN 622-5, by determining the MOE and MOR in bending, draw perpendicular, swelling and water absorption. In the same way, it was analyzed if there is a direct relationship between the bending and tensile perpendicular to face properties. Results showed that the panels studied cannot be considered within the normative standards, despite having attended many of these requirements, for example, in presenting an MOE greater than the relevant standard. Through the analysis of variance, we observed the uniformity of properties in both directions studied. As a result of feedback from the wheel perpendicular and thickness swelling, can admit a bad distribution of the patch panel and a larger amount of paraffin, which was observed by the inconsistency between these properties. Through the low value in the analysis of $\mathrm{R}^{2}$, we can say that there isn't a correlation between the MOR in bending and tensile strength perpendicular.
\end{abstract}

Keywords MDF, Homogeneity, Perpendicular direction, Parallel direction

\section{Introduction}

Wood and wood based products use brings several advantages over other building materials. Wood is a renewable material, widely available, biodegradable and durable depending on the treatment, recycling and immobilizes carbon from the atmosphere in its structure. According Campos [1], Iwakiri [2], Almeida [3], Bertolini [4] and Silva et al. [5] from the various wood resources, with different shapes and dimensions, new wood based products may be generated through its reconstitution, using appropriate methods and for each product type and end use processes. In this context, wood panels can be defined as compounds of elements such as plates, laths, particles and fibers obtained from the reduction of solid wood and reconstituted by adhesive bonding by the action of pressure and temperature.

Wood based panels employing allows the maintenance of many solid wood benefits, such as: panels dimensions not

* Corresponding author:

alchristoforo@yahoo.com.br (André Luis Christoforo)

Published online at http://journal.sapub.org/cmaterials

Copyright $(92014$ Scientific \& Academic Publishing. All Rights Reserved strictly related to trees size; adding value to thinning and sawmill waste materials; possibility of eliminating many defects from wood anatomy as nodes, marrow, grain deviations. These points improve homogeneity of final products related to lumber. Still can, by specifying the density, controlling most of the properties and adding specific products, increase the resistance of the panels to fire and biodegradation [6].

One panel type that replaces solid wood in furniture and floors is the Medium Density Fiberboard (MDF), made from assemblage of wood fibers with synthetic resins and bonded under the joint action of temperature and pressure. To obtain fibers, the wood is cut into small chips which are then milled in equipment called grinders. It is usually used to melamine urea-formaldehyde resin, mixed with fibers in proportions of 10 to $15 \%$ resin, defining MDF type and quality, as pointed out by Campos [1], Campos [6] and Bruno [7].

In Brazil, MDF is a product available from the late 1980s. Initially imported from Argentina and Chile, since September 1997 MDF has been manufactured in Brazil. According to ABIPA [8], Brazilian companies in this segment have currently installed nominal capacity of 5.1 million $\mathrm{m}^{3} /$ year, with production of approximately 3.7 million $\mathrm{m}^{3} /$ year in 2012 . This great potential is assigned 
considering the likely availability of planted forests to be used as raw material and the characteristic of the manufacturing process that adds value to low-quality wood and waste generated by the forest-based industry [9].

MDF can be manufactured with different characteristics, which vary according to their end use, such as "standard" fire resistant; resistant to moisture; and greater mechanical strength plates manufactured with the highest amount of fibers and resins. This allows them to applications requiring higher bending flexural strength or impact performance. MDF thicknesses ranges from 3 to $60 \mathrm{~mm}$ and can be employed in structural, decorative architectural elements and furniture, among others. Several coatings are applied to raw plates to permit uses as laminated flooring and sidings, as cited by Torquato [10].

Resin content is one of the main factors influencing the final panel properties. To identify how these factors interact is very useful for improving the properties of inputs and economy, determining the ideal resin content depending on the desired properties [11-13].

This research analyzed properties of greatest importance from industrial MDF, in directions perpendicular and parallel to the direction of production, to confirm homogeneity along the panel, according to EN 622-5 [14]. It was also treated if it's possible to estimate internal adhesion by means static bending properties.

\section{Material and Methods}

\section{Manufacturing samples}

To determine MDF properties, a commercial $15 \mathrm{~mm}$ raw plate was used. From each direction (perpendicular and parallel to panel production direction) twelve specimens were obtained, as shown in Figure 1, for testing in static bending. After their rupture samples were taken in order to determine internal adhesion, swelling and water absorption.

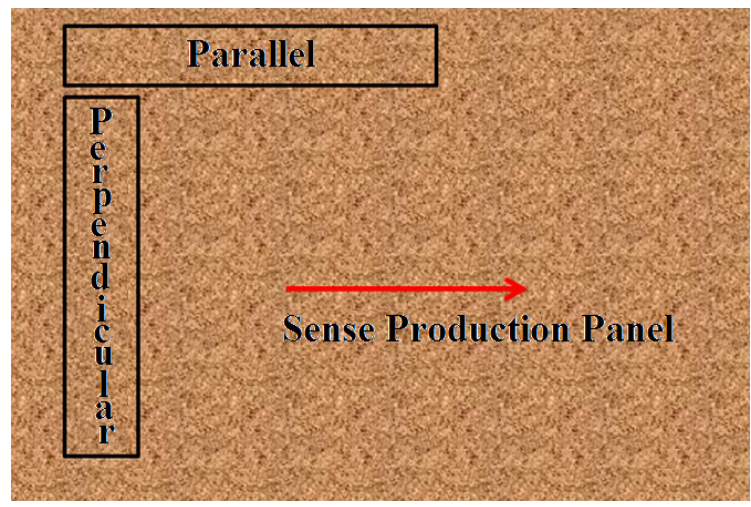

Figure 1. Specimens obtainment

\section{Static bending tests}

Determination of modulus of rupture (MOR) and modulus of elasticity (MOE) based on static bending test was performed according to standard EN 310 [15], using equations 1 and 2 . Specimens were obtained from the plate in mentioned directions, as shown in Figure 1, whose dimensions were established by this standard. Tests were carried out in a $250 \mathrm{kN}$ load capacity universal testing machine Amsler, applying $100 \mathrm{~N}$ increments.

$$
M O E=\frac{\left(P_{50}-P_{10}\right) \cdot L^{3}}{4 \cdot b \cdot f \cdot e^{3}}
$$

Where:

- $\left(\mathrm{P}_{50}-\mathrm{P}_{10}\right)$ : difference between forces $(50 \%$ and $10 \%$ related to estimated rupture $(\mathrm{N})$;

- L: span (cm);

- b: specimen width (cm);

- e: specimen thickness ( $\mathrm{cm})$;

- f: deflection in span middle point $(\mathrm{cm})$.

$$
M O R=\frac{3 \cdot F_{r u p} \cdot L}{2 \cdot b \cdot e^{2}}
$$

Where:

- $\mathrm{F}_{\text {rup: }}$ force in rupture $(\mathrm{N})$.

\section{Tension Perpendicular to Face (Internal Adhesion)}

Tests to determine internal adhesion were conducted according to EN 319 [16]. Specimens for these test, with dimensions required by the standard $(50 \pm 1 \mathrm{~mm}$ edges $)$, were obtained from intact sectors of static bending specimens. Length and width of the specimens were measured and, then, bonded on appropriates wood frames, with a two-component adhesive. Tests were realized 72 hours after this procedure, ensuring adhesive curing. Tests were performed in a $100 \mathrm{kN}$ capacity universal testing machine Dartec, speed of $0.007 \mathrm{~mm} / \mathrm{s}$ (Figure 2).

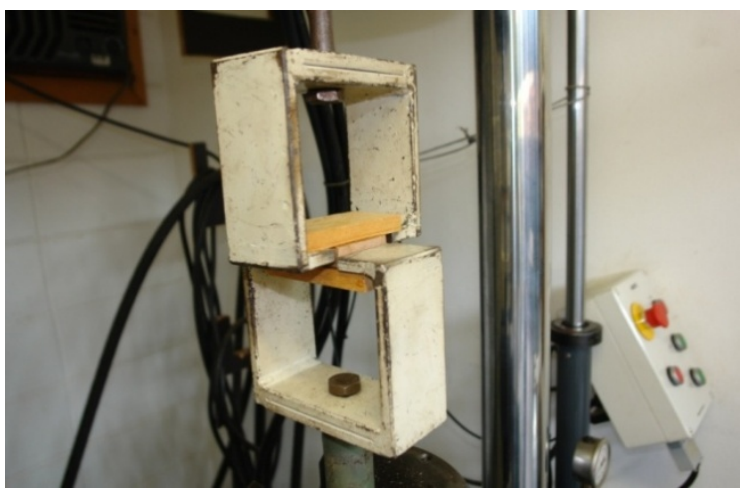

Figure 2. Test of tension perpendicular to face

Tension perpendicular to face strength (internal adhesion) was calculated using Equation 3.

$$
T P=\frac{F_{r u p}}{a \cdot b}
$$

Where:

- $\mathrm{F}_{\text {rup }}$ : force in specimens rupture $(\mathrm{N})$;

- a: specimen length (mm);

- b: specimen width (mm).

\section{Water absorption and thickness swelling}

Values of water absorption and thickness swelling were 
obtained based on methodology proposed by EN 317 [17]. Specimens were immersed in water at a temperature of $20 \pm 1{ }^{\circ} \mathrm{C}$. Then, they were weighed and correspondent thicknesses were measured to determine swelling, related to periods of $2 \mathrm{~h}$ (as performed industrially) and 24 hours (according to standard). Calculations were performed according to the equations 4 and 5 .

$$
A_{m}=100 \cdot \frac{m_{f}-m_{i}}{m_{i}}(\%)
$$

Where:

- $\mathrm{A}_{\mathrm{m}}$ : water absorption (\%);

- $\mathrm{m}_{\mathrm{f}}$ : specimen final mass $(\mathrm{g})$;

- $\mathrm{m}_{\mathrm{i}}$ : specimen initial mass $(\mathrm{g})$.

$$
G_{t}=100 \cdot \frac{t_{f}-t_{i}}{t_{i}}(\%)
$$

Where:

- $\mathrm{G}_{\mathrm{t}}$ : thickness swelling (\%);

- $\mathrm{t}_{\mathrm{f}}$ : specimen final thickness $(\mathrm{mm})$;

- $\mathrm{t}_{\mathrm{i}}$ : specimen initial thickness $(\mathrm{mm})$.

The obtained results were analyzed based on regulatory requirements of EN 622-5 [14] (Table 1), although this code does not comment water absorption.

Table 1. Normative requirements - EN 622-5 [14]

\begin{tabular}{cccc}
\hline Properties & $\begin{array}{c}\text { Test } \\
\text { methods }\end{array}$ & Units & $\begin{array}{c}\text { Nominal } \\
\text { thickness (mm) }\end{array}$ \\
\cline { 4 - 4 } & & $\%$ & 12 \\
\hline Thick. swelling - 24 h & EN 317 & $\%$ & 0.55 \\
Internal Bond & EN 319 & $\mathrm{~N} / \mathrm{mm}^{2}$ & 20 \\
MOR in bending & EN 310 & $\mathrm{~N} / \mathrm{mm}^{2}$ & 2200 \\
MOE in bending & EN 310 & $\mathrm{~N} / \mathrm{mm}^{2}$ & \\
\hline
\end{tabular}

\section{Statistical analysis}

The values of each property, related to the studied directions, were statistically analyzed together using the analysis of variance - one criterion, with assigning a significance level of 5\% (Tukey test) and the aid of program BioEstat 5.0.

\section{Results and Discussions}

Results corresponding to the average values and coefficients of variation $(\mathrm{Cv})$ found for these properties in parallel and perpendicular to the panel production directions, respectively, are shown in Table 2. From Tukey test, different letters following the means represent significant statistical difference at $95 \%$ probability.

By comparing the values here obtained with those established by EN 622-5:2006, it was noted that despite MOE values are shown to be higher than the minimum regulatory requirements, MOR values are lower, for the two directions studied. Coefficients of variation are smaller than $0.1(10 \%)$, for these properties, turning possible to admit product uniformity related to these properties.

Regarding the thickness swelling (24h), results showed to be satisfactory, being below the maximum allowed by the relevant regulatory requirements.

In water absorption test, it is found that coefficient of variation ( $2 \mathrm{~h}$ ) is greater than after 24 hours of exposure, both parallel and perpendicular directions, once fibers present high susceptibility to water absorption, due to the hydrogen links. This leads to expansion of the polymer chains and generates voids between fibers, which are filled with water in the early stage.

In the second stage (24h), panel low expansion is due to the absence of voids between fibers that connect water to the polymer chains by hydrogen bonds. Paraffin, because of its hydrophobic character, aims to maintain panel stability, but their properties are lost in initial stage of the test due to the severity of specimen exposure.

MDF standards do not provide values for the water absorption. In this sense, results for this property were compared to Eleotério [18], who produced MDF from Pinus $\mathrm{sp}$ with different levels of urea formaldehyde resin and $1 \%$ wax (in relation to particles mass). Eleotério [18] obtained for water absorption in 24 hours, values near $35 \%$, when used amounts of 8 to $12 \%$ resin for the production of panels. However, comparison of these values is hampered by the unfamiliarity of production conditions of MDF commercial used in the present study.

\begin{tabular}{|c|c|c|c|c|c|c|}
\hline \multirow{3}{*}{ Properties } & \multirow{3}{*}{ Test methods } & \multirow{3}{*}{ Units } & \multicolumn{4}{|c|}{ Direction } \\
\hline & & & \multicolumn{2}{|c|}{ Parallel } & \multicolumn{2}{|c|}{ Perpendicular } \\
\hline & & & Average & $\mathrm{Cv}(\%)$ & Average & $\mathrm{Cv}(\%)$ \\
\hline Thickness swelling $-2 \mathrm{~h}$ & industrial & $\%$ & $3.9 \mathrm{a}$ & 16 & $3.4 \mathrm{~b}$ & 17 \\
\hline Thickness swelling - $24 \mathrm{~h}$ & EN 317 & $\%$ & $10.3 \mathrm{a}$ & 17 & $10.9 \mathrm{a}$ & 16 \\
\hline Water absorption $-2 \mathrm{~h}$ & industrial & $\%$ & $12.2 \mathrm{a}$ & 17 & $12 \mathrm{a}$ & 13 \\
\hline Water absorption $-24 \mathrm{~h}$ & - & $\%$ & $35.6 \mathrm{a}$ & 9 & $36 \mathrm{a}$ & 8 \\
\hline Internal Bond & EN 319 & $\mathrm{~N} / \mathrm{mm}^{2}$ & $0.35 \mathrm{a}$ & 24.3 & $0.32 \mathrm{a}$ & 26.8 \\
\hline MOR in bending & EN 310 & $\mathrm{~N} / \mathrm{mm}^{2}$ & $15.8 \mathrm{a}$ & 5.7 & $15.9 \mathrm{a}$ & 4.8 \\
\hline MOE in bending & EN 310 & $\mathrm{~N} / \mathrm{mm}^{2}$ & $2.731 \mathrm{a}$ & 6.4 & $2.898 \mathrm{a}$ & 8 \\
\hline
\end{tabular}

Table 2. Panel properties in analyzed directions 
Regarding the results obtained in internal bond, it is observed that commercial samples do not meet the standard EN 622-5 [14], for both directions studied. Furthermore, the coefficients of variation are elevated, possibly due to a considerable amount of paraffin relative to the adhesive used in these MDF panels, resulting in a loss of performance in relation to this property. It is emphasized that this property of the commercial MDF panels is considerably less than those panels studied currently containing resins with lower environmental impact, as the polyurethanes based on castor oil. Silva et al. [5] obtained for panels from Pinus and Eucalyptus and castor oil based resin, 1.42 and $1.16 \mathrm{MPa}$ panels, respectively, demonstrating the possibility of industries to adopt new inputs to achieve superior performance.

In studies with commercial MDF of Pinus and Eucalyptus, Torquato [10] found a similar situation, with MOE results meting normative requirements (in both parallel and perpendicular directions), but did not reaching the minimum required to internal adhesion. The higher value found for the rigidity in this study and in the cited paper could be attributed to the fact that, despite associate themselves low tension perpendicular to face values with less adhesive employed, this would be a uniform distribution over the panel, resulting in efficiency in stress distribution between fibers upon mechanical loads.

Analysis of variance revealed that properties, when compared in both directions considered, were statistically equivalent ( $p>0.05$ ), except to thickness swelling ( $2 \mathrm{~h}$ ) with respect to the parallel direction and perpendicular, once they were statistically different $(\mathrm{p}<0.05)$, as shown in Table 2 . However, this property at $2 \mathrm{~h}$ is not established by EN 622-5 [14].

Graphics of MOR dispersion versus internal adhesion were plotted to analyze correlation between these properties, so that a property can be estimated by means of another. This correlation was analyzed using the $\mathrm{R}^{2}$ value of the line. The direction of each respective panel analyzed is shown in figures 3 and 4.

Through the analysis of the corresponding graphs (Figures 3 and 4), it is observed, by the fact that $\mathrm{R}^{2}$ is far smaller than $0.8(80 \%)$ [19], in both directions studied, that there is no possibility of estimating internal adhesion using MOR.

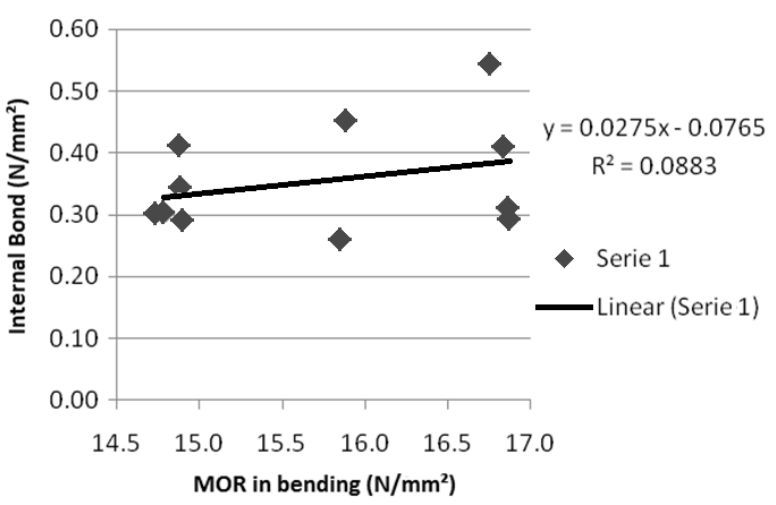

Figure 3. Comparison between MOR and internal bond, parallel to panel direction

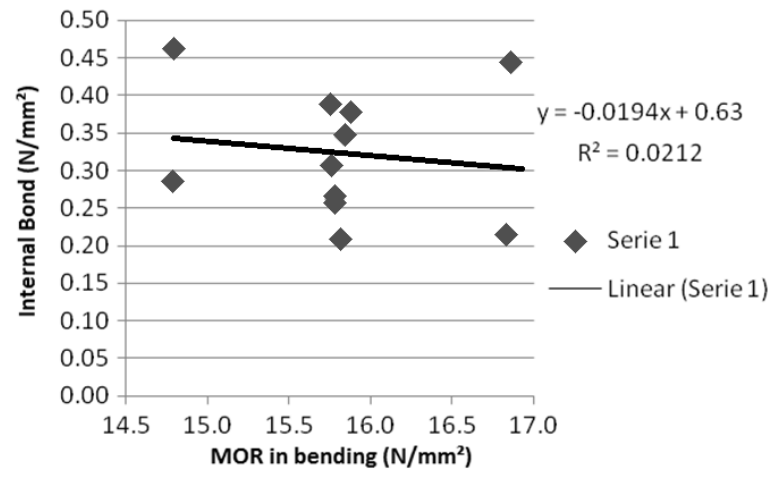

Figure 4. Comparison between MOR and internal bond, perpendicular to panel direction

\section{Conclusions}

Results obtained in this study showed that:

- EN 622-5:2006 requirements were not reached to MOR and internal adhesion;

- Limits imposed by EN 622-5 [14], related to thickness swelling, were reached, but results of internal adhesion can point out that paraffin content is very high;

- Homogeneity can be accepted once the properties are statically equivalents in both studied directions;

- With $\mathrm{R}^{2}<0.8$ it is not possible to establish correlation between MOR and internal adhesion.

\section{REFERENCES}

[1] Campos, C. I.; Rocco Lahr, F. A. Production and characterization of MDF using eucalyptus fibers and castor oil-based polyurethane resin. Materials Research (São Carlos. Impresso), São Carlos - SP, v. 7, n.3, p. 421-425, 2004.

[2] Iwakiri, S. Painéis de madeira reconstituída. FUPEF. Curitiba, 254 p., 2005.

[3] Almeida, D. H.; Ferro, F. S.; Varanda, L. D.; Souza, A. M.; Icimoto, F. H.; Christoforo, A. L.; Lahr, F. A. R. Quality control in plywood manufacturing: physical properties of commercial plywood of Pinus sp. International Journal of Composite Materials, v. 3, p. 163-167, 2013.

[4] Bertolini, M. S.; Rocco Lahr, F. A.; Nascimento, M. F.; Agnelli, J. Accelerated artificial aging of particleboards from residues of $\mathrm{CCB}$ treated Pinus $\mathrm{sp}$ and castor oil resin. Materials Research (São Carlos. Impresso), v. 16, p. 293-303, 2013.

[5] Silva, S. A. M.; Christoforo, A. L.; Goncalves, R.; Rocco, F. A. L. Strength Properties of Medium Density Fiberboards (MDF) Manufactured with Pinus elliottii wood and Polyurethane Resin Derived From Castor Oil. International Journal of Composite Materials, v. 3, p. 7-14, 2013.

[6] Campos, C. I. Produção e caracterização de MDF a partir de fibras de madeira de reflorestamento e adesivos alternativos em diferentes teores. Tese de Doutorado (Ciências e Engenharia de Materiais), Escola de Engenharia de São Carlos da Universidade de São Paulo, São Carlo-SP, 2005. 
[7] , E. G. Painéis facilitam usinagem na fabricação moveleira. Revista da madeira, No109, 2007.

[8] Associação Brasileira da Indústria de Painéis de Madeira (ABIPA) 2013. Disponível em: <http://www.abipa.org.br/pr odutosMDF.php $>$. Acesso em: 27 jan. 2014.

[9] Silva, S. A. M. Chapa de média densidade (MDF) fabricada com poliuretana mono-componete derivada de óleo de mamona caracterização por método destrutivo e por ultra-som. Tese de Doutorado (Ciências e Engenharia de Materiais), Escola de Engenharia de São Carlos da Universidade de São Paulo, São Carlo-SP, 2003.

[10] Torquato, L. P. Caracterização dos painéis MDF comerciais produzidos no Brasil. 2008. 94f. Dissertação (Mestrado) Setor de Ciências Agrárias, Universidade Federal do Paraná, Curitiba.

[11] Silva, S. A. M.; Christoforo, A. L.; Panzera, T. H.; Almeida, D. H.; Segantini, A. A. S.; Lahr, F. A. R. Particleboard manufactured with Leucena wood and polyurethane resin castor oil based. Ciência Rural (UFSM. Impresso), v. 43, p. 1399-1404, 2013.

[12] Alves, L. S.; Silva, S. A. M.; Azambuja, M. A.;Varanda, L. D.; Christoforo, A. L.; Rocco, F. A. L. Particleboard produced with sawmill waste of different wood species. Advanced Materials Research (Online), v. 884-885, p. 689-693, 2014.

[13] Ferro, F. S.; Almeida, D. H.; Souza, A. M.; Icimoto, F. H.; Christoforo, A. L.; Rocco, F. A. L. Influence of Proportion Polyol/Pre-Polymer Castor-oil Resin Components in Static
Bending Properties of Particleboards Produced with Pinus sp. Advanced Materials Research (Online), v. 884-885, p. 667-670, 2014.

[14] European Committee for Standardization. European Standard EN 622 - Tableros de fibras - Especificaciones. Parte 5: Requisitos de los tableros de fibras fabricados por proceso seco. Bruxelas, 2006.

[15] European Committee for Standardization. European Standard EN 310 - Wood-based panels - Determination of modulus of elasticity in bending and of bending strength. Bruxelas: 1993.

[16] European Committee for Standardization. European Standard EN 319 - Particleboards and Fiberboards - Determination of tensile strength perpendicular to the plane of the board. Bruxelas: 1993.

[17] European Committee for Standardization. European Standard EN 317 - Particleboards and Fiberboards - Determination of swelling in thickness after immersion in water. Bruxelas: 1993.

[18] Eleotério, J. R. Propriedades físicas e mecânicas de painéis MDF de diferentes densidades e teores de resina. 2000. $122 \mathrm{f}$. Dissertação (Mestrado) - Escola Superior de Agricultura "Luiz de Queiroz", Universidade de São Paulo, Piracicaba.

[19] Montgomery, D. C. Design and analysis of experiments. John Wiley \& Sons Inc., 6a edition, Arizona, 2005. 